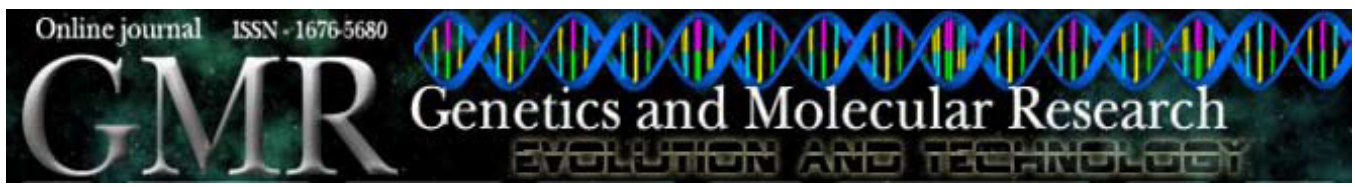

\title{
Three novel SNPs of the bovine $T f$ gene in Chinese native cattle and their associations with milk production traits
}

\author{
Z.H. Ju, Q.L. Li, J.M. Huang, M.H. Hou, R.L. Li, J.B. Li, J.F. Zhong \\ and C.F. Wang \\ Dairy Cattle Research Center, Shandong Academy of Agricultural Sciences, \\ Jinan, Shandong Province, China \\ Corresponding author: C.F. Wang \\ E-mail:wcf1967@yahoo.com.cn
}

Genet. Mol. Res. 10 (1): 340-352 (2011)

Received August 25, 2010

Accepted November 24, 2010

Published March 1, 2011

DOI 10.4238/vol10-1gmr1038

\begin{abstract}
Transferrin (Tf) is a $\beta$-globulin protein that transports iron ions in mammalian cells. It contributes to innate immunity to microbial pathogens, primarily by limiting microbial access to iron. Thus, polymorphisms present in bovine Tf could potentially underlie inherited differences in mastitis resistance and milk production traits. We detected three novel single-nucleotide polymorphisms of the $T f$ gene in Chinese native cattle by screening for genetic variation of $T f$ in 751 individuals of three Chinese cattle breeds, namely China Holstein, Luxi Yellow and Bohai Black, using PCR-RFLP and DNA sequencing techniques. The three new SNPs, g.-1748G >A ss250608649, g.13942T >C ss250608650, and g.14037A $>\mathrm{G}$ ss250608651, had allele frequencies of 85.9, 86.3 and $92.5 \%, 64.5,73.3$ and $65.0 \%$, and $67.6,73.7$ and $60.0 \%$, respectively. SNP g.-1748G $>$ A was located in the 5' flanking region of $T f$. SNP g.14037A $>$ G was located in intron 8 of $T f$. SNP g.13942T $>$ C, located in exon 8 of $T f$, was a synonymous mutation (TTA $>$ CTA), encoding a leucine (326 aa) in the Tf protein. Associations of the Tf SNPs with milk traits were also analyzed. Significant $(\mathrm{P}<0.05)$ relationships among the $T f$ polymorphisms, somatic cell scores (SCS), and milk productive traits were observed. Cows with genotypes TT (g.13942T>C),
\end{abstract}


$G G$ (g.-1748G $>$ A) and $A G($ g. $14037 \mathrm{~A}>\mathrm{G}$ ) had a lower SCS and higher protein levels and 305-day milk yield. Nineteen combinations of different haplotypes from the three SNPs were identified in Chinese Holstein cattle. The haplotype combination ATA/GCA, GCA/GCA and GCG/ GTA was dominant in cows with a lower SCS, a higher protein level and a higher 305-day milk yield, respectively. Moreover, the gene expression level of Tf was higher in mastitis-affected mammary tissues than in normal mammary tissues. These results suggest that the $T f$ gene affects milk production, as well as mastitis-resistance traits, in Chinese Holsteins.

Key words: Chinese native cattle; Transferrin; SNPs; Milk production traits; Somatic cell score

\section{INTRODUCTION}

The health status of the mammary gland greatly affects the biological value of collected milk (Sevi et al., 2001). Mastitis in dairy cattle is a common and costly inflammatory disease of the mammary gland caused by intramammary infections, and leads to reduced yield, degraded quality, reduced lactation persistency, and early culling of cow (Seegers et al., 2003). Environmental and contagious pathogens including Escherichia coli, Streptococcus dysgalactiae, Streptococcus uberis, Staphylococcus aureus, and Streptococcus agalactiae are by far the main causes of mastitis (Mason, 2006). Breed improvement programs have been proven useful for the selection of positive milk production traits, but are expensive and time-consuming. Therefore, marker-assisted selection that supports fast and low-cost genetic progress and improves the accuracy of selection is desirable. In this regard, it is useful to study the genetic variations of candidate genes and their associations with milk production and somatic cell count (SCC) (Khatib et al., 2007; Huang et al., 2010), which have a high genetic positive correlation with mastitis (with an estimated average coefficient of 0.7) (Pösö and Mäntysaari, 1996; Heringstad et al., 2000).

Transferrin (Tf) is an iron-binding $\beta$-globulin plasma protein synthesized by the liver with a molecular weight of about $80 \mathrm{kDa}$ (Fletcher and Huehns, 1968). It has two separate iron-binding sites, and each of them is capable of binding one atom of ferric iron (Fletcher and Huehns, 1968). In human plasma, transferrin is normally at $2.0-3.2 \mathrm{mg} / \mathrm{mL}$ and is typically onethird saturated with iron (Macgillivray et al., 1982). Transferrin may contribute to innate host defense against bacterial and fungal pathogens by limiting microbial access to iron (Chaneton et al., 2008). Transferrin also inhibits bacterial adhesion (Ardehali et al., 2003) and has an ironindependent antifungal effect (Bond et al., 2005). In addition, in animals with diagnosed mastitis, the transferrin concentration in milk is higher than that in healthy animals (Kmiec, 1998). These results suggest a possible relationship between the $T f$ gene and mastitis in dairy cattle.

The $T f$ gene is located on bovine chromosome 1q41-q46 (Chowdhary et al., 1998), where it consists of 17 exons and spans about $39 \mathrm{~kb}$ of genomic DNA. Many polymorphisms have been found in the bovine $T f$ gene (Ashton et al., 1964; Zhang et al., 2008; Sanz et al., 2010). Twelve co-dominant alleles of $T f$ have been identified from a single locus using starch gel electrophoresis. A, D1, D2, and E are the major variants that have been described (Gahne et al., 1977). However, little is known about the $T f$ single nucleotide polymorphisms (SNPs) and their associations with infectious diseases such as bovine mastitis. 
Chinese Holstein cattle are derived from crossbreeding and selection between the Chinese native cow and pure-bred Holstein bull. The frequency of mastitis in the breed is about $38-50 \%$ (Tao et al., 2007). Luxi Yellow cattle and Bohai Black cattle are two representative indigenous bovine (Bos taurus) breeds in China, which have been bred as beef and draft dualpurpose cattle for thousands of years because of their low disease frequencies and high endurance with unfavorable feeding conditions. Here, we detected polymorphisms of the $T f$ gene in three Chinese cattle breeds, and assessed the associations of these polymorphisms with milk production and mastitis-related traits. Tf gene expression in normal and mastitis mammary tissues in Chinese Holstein was also assessed by fluorescence quantitative real-time polymerase chain reaction (qRT-PCR).

\section{MATERIAL AND METHODS}

\section{Animals}

A total of 751 individuals of three cattle breeds in China, including Chinese Holstein $(\mathrm{N}=576)$, Luxi Yellow cattle $(\mathrm{N}=135)$, and Bohai Black cattle $(\mathrm{N}=40)$, were used in the study. Milk production (305-day milk yield), somatic cell score (SCS), and fat and protein contents in Chinese Holstein from 23 sires were obtained by the Dairy Herd Improvement Laboratory, Dairy Cattle Research Center, Academy of Agricultural Sciences of Shandong Province, using a milk composition analyzer (Foss MilkScan FT 6000, Denmark).

\section{Genomic DNA extraction}

Genomic DNA was isolated from bovine blood samples by the phenol-chloroform method. DNA concentration was estimated spectrophotometrically and then adjusted to $50 \mathrm{ng} /$ $\mu \mathrm{L}$. All DNA samples were stored at $-20^{\circ} \mathrm{C}$.

\section{PCR amplification and sequencing}

Seven primer pairs (Table 1) were designed using the PRIMER PREMIER 5.0 software (Premier, Canada) to amplify the bovine $T f$ gene (NW_001493777) including exon 6-8, boundaries of each exon and intron, and the 5' flanking region. Primers P1-P5 were used to sequence the 5 ' flanking region and exon 6-8. The PCR mixture with a final volume of $25 \mu \mathrm{L}$ consisted of $2.5 \mu \mathrm{L} 10 \mathrm{X}$ buffer, $1.2 \mu \mathrm{L} 50 \mathrm{mM} \mathrm{Mg}^{2+}$, $0.6 \mu \mathrm{L} 10 \mathrm{mM}$ dNTPs, $0.8 \mu \mathrm{L} 10 \mu \mathrm{M}$ of each primer, $1.0 \mu \mathrm{L} 50 \mathrm{ng} / \mu \mathrm{L}$ genomic DNA, $0.5 \mu \mathrm{L} 5 \mathrm{U} / \mu \mathrm{L}$ Taq DNA polymerase (TaKaRa,

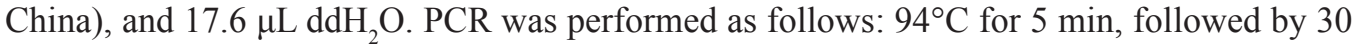
cycles of $94^{\circ} \mathrm{C}$ for $30 \mathrm{~s}$, annealing (temperatures see Table 1) for $30 \mathrm{~s}$, and $72^{\circ} \mathrm{C}$ for $30 \mathrm{~s}$, and a final extension at $72^{\circ} \mathrm{C}$ for $8 \mathrm{~min}$. PCR products were evaluated by electrophoresis on $1 \%$ agarose gels after staining with ethidium bromide, and directly sequenced using an ABI PRISM ${ }^{\mathrm{TM}}$ 3730 DNA Sequencer (Applied Biosystems, USA) and a BigDye terminator v3.1 Sequencing Kit (Shanghai Sangon, China). Sequence data were analyzed with the DNAMAN software (Version 4.0, Lynnon Corporation, Quebec, Canada) to identify SNPs, and SNPs were then confirmed using restriction fragment length polymorphism (RFLP) or created restriction site PCR (CRS-PCR). 


\begin{tabular}{|c|c|c|c|c|}
\hline Loci & Position & Primer sequence $\left(5^{\prime}-3^{\prime}\right)$ & $\operatorname{Tm}\left({ }^{\circ} \mathrm{C}\right)$ & Size of amplicon (bp) \\
\hline Tf P1 & $12398 \sim 13256$ & $\begin{array}{l}\mathrm{F}: \text { CCTGCAAGAACCTCCCTAATG } \\
\text { R }\end{array}$ & 60 & 859 \\
\hline Tf P2 & $13728 \sim 14609$ & $\begin{array}{l}\text { F: GGTCTGACTGCCCTCTCTC } \\
\text { R: GTTCAAACACACCTCTAATG }\end{array}$ & 57 & 882 \\
\hline Tf P3 & $-2055 \sim-1158$ & $\begin{array}{l}\text { F: TGGGCAGATTTGCAAGCTC } \\
\text { R: ATCCAACTCGATCAGATGGTC }\end{array}$ & 60 & 898 \\
\hline Tf P4 & $-1230 \sim-366$ & $\begin{array}{l}\text { F: GACATATCTTCTAAGCCTGG } \\
\text { R: CTGGTCCTGAATCAACCTC }\end{array}$ & 60 & 865 \\
\hline Tf P5 & $-459 \sim 41$ & $\begin{array}{l}\text { F: GGTCTCTGCCTGTCTTCCTCCTA } \\
\text { R: AGAACCGCGCAGGCTAACAG }\end{array}$ & 60 & 501 \\
\hline Tf P6 & $-1903 \sim-1727$ & $\begin{array}{l}\text { F: CACTCCCTAATGCCTGATAC } \\
\text { R: CAGGGACTTTCTGTTTACC }{ }^{*} A\end{array}$ & 54 & 177 \\
\hline Tf P7 & $14014 \sim 14177$ & $\begin{array}{l}\text { F: AGAGAAAGTAAACGTAAGTATC }{ }^{*} \mathrm{C} \\
\text { R: ATTTATCATCCGTCTAACACTG }\end{array}$ & 55 & 164 \\
\hline
\end{tabular}

In primer $\mathrm{P}$, the asterisk indicates a mutation (A to C) that creates an StyI restriction site $\left(\mathrm{C}^{\wedge} \mathrm{CWWGG}\right)$. In primer $\mathrm{P} 7$, the asterisk indicates a mutation (T to $\mathrm{C}$ ) that creates an $M s p \mathrm{I}$ restriction site $\left(\mathrm{C}^{\wedge} \mathrm{CGG}\right)$.

\section{Genotyping tests}

According to sequencing results, primer pairs P6, P2 and P7 were used to test for genetic variation. Enzymes StyI, DraI and MspI were used to digest PCR products. The PCR product using primer pair $\mathrm{P} 2$ included a natural DraI endonuclease restriction site (TTT^AAA), whereas the DNA fragment obtained from PCR using primer pairs P6 and P7 had no suitable endonuclease restriction site and was therefore genotyped by CRS-PCR. Primers for CRSPCR contained nucleotide mismatches that enabled the use of restriction enzymes to discriminate sequence variations. Specifically, the second base A from the 3' end of primer P6R was replaced by $\mathrm{C}$, which created an $S t y \mathrm{I}$ restriction site $\left(\mathrm{C}^{\wedge} \mathrm{CWWGG}\right)$; the second base $\mathrm{T}$ from the $3^{\prime}$ end of primer $\mathrm{P} 7 \mathrm{~F}$ was replaced by $\mathrm{C}$, which created an $M s p \mathrm{I}$ restriction site $\left(\mathrm{C}^{\wedge} \mathrm{CGG}\right)$ (Table 1). Aliquots $(5 \mu \mathrm{L})$ of PCR products were digested with 10 units of restriction enzyme for $8 \mathrm{~h}$ at $37^{\circ} \mathrm{C}$ following supplier instructions. Digested PCR products were subjected to $10 \%$ PAGE $(80 \times 73 \times 0.75 \mathrm{~mm})$ electrophoresis in $1 \mathrm{X}$ TBE buffer at a constant voltage of $110 \mathrm{~V}$ for $3.5 \mathrm{~h}$ at room temperature. Gels were stained with $0.1 \%$ silver nitrate, and the genotype was determined based on different electrophoresis patterns.

\section{Fluorescence quantitative real-time PCR}

Twelve mammary tissues from 10 culled Chinese Holstein cattle with clinical mastitis were divided into two groups: normal $(\mathrm{N}=6)$ and mastitis $(\mathrm{N}=6)$ mammary. Total RNA was isolated from the 12 mammary tissues using TRIzol reagent (Bioteke, Beijing, China) according to the manufacturer instruction. cDNA was synthesized using the transcriptor firststrand cDNA synthesis kit (TaKaRa). Real-time PCR was performed in a $20-\mu \mathrm{L}$ mixture containing $50 \mathrm{ng}$ cDNA, $0.4 \mu \mathrm{M}$ sense and antisense primers each, $6.8 \mu \mathrm{L} \mathrm{ddH}_{2} \mathrm{O}, 10.0 \mu \mathrm{L}$ $\mathrm{SYBR}^{\circledR}$ Premix Ex Taq ${ }^{\mathrm{TM}}(2 \mathrm{X})$, and $0.4 \mu \mathrm{L}$ ROX Reference Dye (50X) (TaKaRa). To normalize the differences in the amount of total cDNA added to each reaction, the $\beta$-actin gene was used as an endogenous control. The reaction mixture was denatured for $30 \mathrm{~s}$ at $95^{\circ} \mathrm{C}$, followed by 40 cycles of $5 \mathrm{~s}$ at $95^{\circ} \mathrm{C}$ and $31 \mathrm{~s}$ at $60^{\circ} \mathrm{C}$. The primers used were $T f(\mathrm{NM}$ - 177484) sense 
(5'-ATGCTCAACCTCAAAACTCC-3'), Tf antisense (5'-ATCACTCAGACCAGCGAAAC-3'), $\beta$-actin (NM_173979) sense (5'-GCACAATGAAGATCAAGATCATC-3'), and $\beta$-actin antisense (5'-CTAACAGTCCGCCTAGAAGCA-3'). PCR was monitored by the ABI PRISM 7000HT Fast Real-Time PCR system (Applied Biosystems). Relative quantification of the $T f$ gene expression was calculated using the standard curve-based method for relative real-time PCR (Larionov et al., 2005).

\section{Statistical analysis}

The genotypic frequencies, allelic frequencies, polymorphism information content $(P I C)$, heterozygosity $\left(H_{e}\right)$ and effective number of alleles $\left(N_{e}\right)$ were calculated using the POPGENE, version 1.31, software (Molecular Biology and Biotechnology Centre, University of Alberta, Canada). The genotype distributions in different breeds were tested for HardyWeinberg equilibrium using the appropriate chi-square $\left(\chi^{2}\right)$ test. The linkage disequilibrium and haplotype frequencies were estimated using the SHEsis software (Shi and He, 2005).

The distribution frequency of SCC is usually inhomogeneous and SCS is a commonly used parameter based on SCC. Cow SCS was calculated with SCS $=\log _{2}(\mathrm{SCC} / 100)+3$, where SCC is cell number/ $\mu \mathrm{L}$ (Rupp and Boichard, 1999).

The associations among genotypes, haplotype combinations of $T f$ gene, and milk production and healthy traits were analyzed using the least-squares method of the general linear model procedure of the SAS software V8.1 (SAS Institute Inc., Cary, NC, USA). Fixed effects of genotypes, haplotype combinations, and season of birth and parity were included as independent variables. In the formula $Y_{i j k l} \mu+G_{i}+S_{j}+H_{k}+P_{l}+e_{i j k l}, Y_{i j k l}$ is observed value, $\mu$ is mean value, $G_{i}$ is fixed effect of $i$ th genotype or $i$ th haplotype, $S_{j}$ is fixed effect of $j$ th season $(\mathrm{j}=1$ to 2$), H_{k}$ is fixed effect of $k$ th farm $(\mathrm{k}=1$ to 20$), P_{l}$ is fixed effect of $l$ th parity $(1=1$ to 4$)$, and $e_{i j k l}$ is random residual effect. Additive and dominance effects of every locus were evaluated separately. Values of $\mathrm{P}<0.05$ were regarded as significant.

\section{RESULTS AND DISCUSSION}

\section{Genetic polymorphisms of $T f$ gene in Chinese cattle}

Three novel SNPs g.-1748G $>$ A (5' flanking regions), g.13942T $>$ C (exon 8) and g. 14037A $>\mathrm{G}$ (intron 8) were revealed from 50 samples (15 from Luxi Yellow, 15 from Bohai Black, and 20 from Chinese Holstein randomly selected from different farms) by direct sequencing and comparisons with the reference sequence (NW_001493777) (Figure 1). No SNPs were detected in the P1, P4, and P5 loci. The sequences of SNPs g.-1748G $>$ A, g.13942T $>$ C and g. 14037A $>$ G were submitted to the National Centre for Biotechnology Information under accession Nos. ss250608649, ss250608650, and ss250608651, respectively.

Digestions of the PCR products of $T f$ g.-1748G $>$ A locus with StyI produced 111- and 66-bp fragments for genotype $G G, 111-, 93$ - and 66-bp fragments for genotype $G A$, and 93- and 66-bp fragments for genotype $A A$. Digestions of the PCR products of $T f \mathrm{~g} .13942 \mathrm{~T}>\mathrm{C}$ locus with DraI produced 666- and 216-bp fragments for genotype TT, 882-, 666- and 216-bp fragments for genotype $T C$, and an 882-bp fragment for genotype $C C$. Digestions of the PCR products of $T f$ g.14037A $>\mathrm{G}$ locus with MspI produced an 164-bp fragment for genotype $A A, 164-, 142-$ and 22-bp fragments for genotype $A G$, and 142- and 22-bp fragments for genotype $G G$ (Figure 2). 


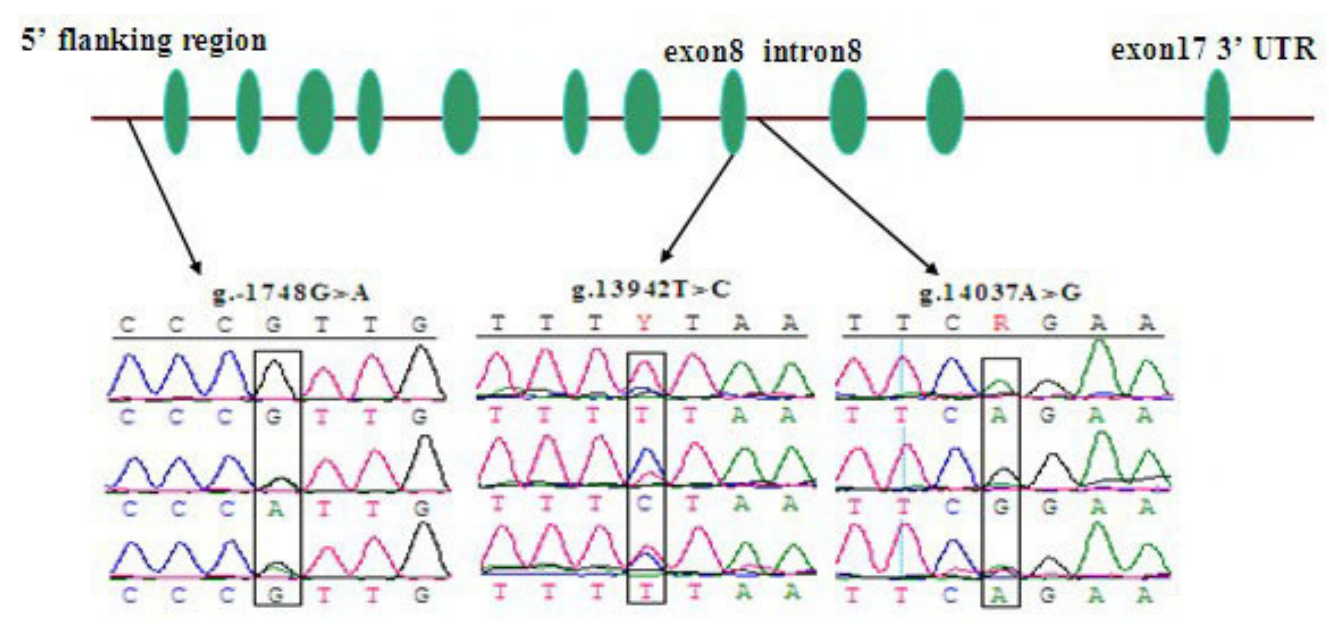

Figure 1. $T f$ structure, location of SNPs and sequencing results of the three genotypes g.-1748G $>$ A ss 250608649 , g.13942T $>C$ ss 250608650 , and g.14037A $>$ G ss250608651.

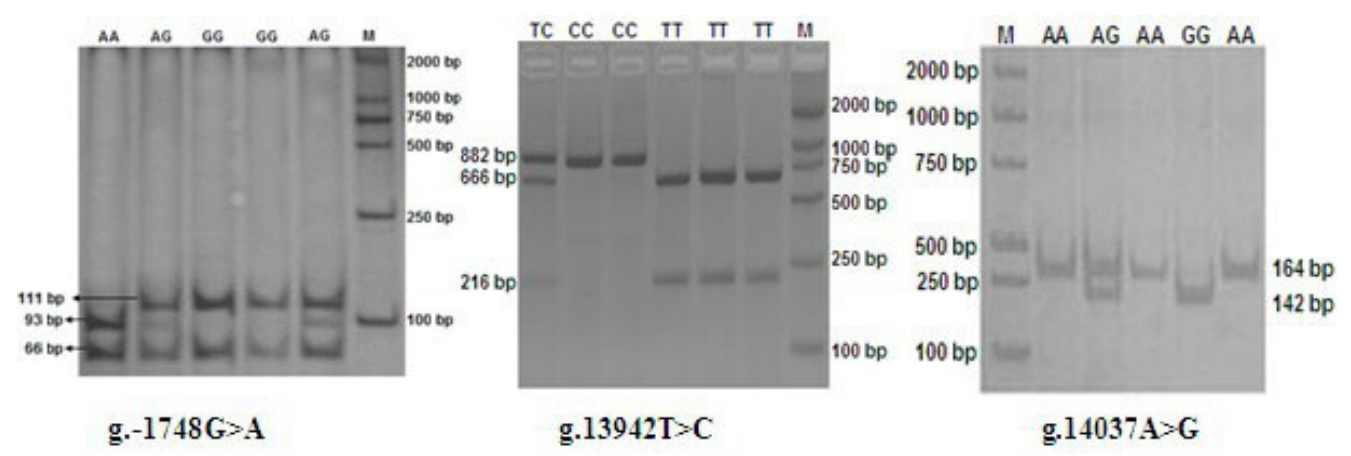

Figure 2. Silver-stained gels showing band patterns of SNPs g.-1748G $>$ A, g.13942T $>$ C and g.14037A $>$ C digested with StyI, DraI and MspI, respectively. Digestions of PCR products of $T f$ g.-1748G $>$ A locus with StyI produced 111- and 66-bp bands for homozygous genotype $G G, 111$-, 93- and 66-bp bands for heterozygous genotype $A G$, 93- and 66-bp bands for homozygous genotype $A A$. Digestions of PCR products of $T f \mathrm{~g}$. 13492T $>\mathrm{C}$ locus with $\mathrm{DraI}$ resulted in 666- and 216-bp bands for genotype TT, 882-, 666- and 216-bp bands for genotype TC, and a 882-bp band for genotype $C C$. Digestions of the PCR products of $T f$ g.14037A $>$ G locus with MspI generated 164-, 164and 142-bp bands, and an 142-bp band for genotypes $A A, A G$ and $G G$, respectively. Bands smaller than 50 bp are not shown.

The genotypic frequencies, allelic frequencies and genetic indices $\left(P I C, H_{e}, N_{e}\right.$, and $\chi^{2}$ test) in the three Chinese cattle populations are summarized in Table 2. Alleles $G, T$ and $A$ were the dominant alleles at positions g. $-1748 \mathrm{G}>$ A, g.13942T $>$ C and g.14037A $>$ G in the three cattle breeds, respectively. At locus g.-1748G $>$ A, the genotypic frequencies of the three cattle populations with genotype $G G$ were higher than the ones with genotype $A A$, and the locus possessed low genetic diversity $(\mathrm{P}<0.25)$ (Table $2 \mathrm{~A})$. The three Chinese cattle breeds possessed intermediate genetic diversity $(0.25<\mathrm{P}<0.50)$ at g. $13942 \mathrm{~T}>\mathrm{C}$ and g. $14037 \mathrm{~A}>\mathrm{G}$ loci, which suggested that there was an intermediate genetic diversity for the Chinese bovine 
Tf gene in the populations analyzed (Table 2B and C). The PIC, $H_{e}$, and $N_{e}$ of loci g.13942T $>\mathrm{C}$ and g. 14037A $>\mathrm{G}$ in Chinese Holstein and Bohai Black cattle were higher than those in the Luxi Yellow breed, indicating that the polymorphism and genetic variation of Chinese Holstein and Bohai Black cattle were higher than those of the Luxi Yellow breed at these two loci. The results of the $\chi^{2}$ test showed that all SNPs in the three populations agreed with the Hardy-Weinberg equilibrium (Table 2) $(\mathrm{P}>0.05)$, indicating that the selection pressure on the three SNPs in the populations was not too powerful. In most cases, the theoretical numbers of the genotypic and allelic frequencies in beef cattle were different from the actual numbers in dairy cattle (Zhang et al., 2010; Liu et al., 2010), but they were almost the same in this study, which implied that the Tf gene could be very conserved. This coincides with a previous finding that transferrins had a substantial degree of conservation in amino acid sequence $(>70 \%)$ and a very similar overall tertiary structure (Retzer et al., 1996). In addition, phylogenetic studies showed that the exon/intron pattern was very similar among human transferrin, mouse lactoferrin and chicken ovotransferrin genes (Retzer et al., 1996). In our study, the linkage disequilibrium among the three SNPs in the population was estimated (data not shown), and the SNPs were unlinked $\left(r^{2}=0.032-0.374\right)$.

Table 2. Genotypic and allelic frequencies and Hardy-Weinberg equilibrium $\chi^{2}$ test of $T f$ gene at positions: A. g. $-1748 \mathrm{G}>$ A, B. g. $13942 \mathrm{~T}>$ C and C. g.14037A $>$ G.

A.

\begin{tabular}{|c|c|c|c|c|c|c|c|c|c|}
\hline \multirow[t]{2}{*}{ Breed } & \multicolumn{3}{|c|}{ Observed genotype } & \multicolumn{2}{|c|}{ Allelic frequency } & \multirow[t]{2}{*}{$P I C$} & \multirow[t]{2}{*}{$H_{e}$} & \multirow[t]{2}{*}{$N_{e}$} & \multirow[t]{2}{*}{$\chi^{2}$ test $(\mathrm{P})$} \\
\hline & GG & GA & AA & G & A & & & & \\
\hline $\mathrm{CH}$ & 424 & 141 & 11 & & & & & & \\
\hline 576 & 0.736 & 0.245 & 0.019 & 0.859 & 0.141 & 0.213 & 0.243 & 1.321 & 0.033 \\
\hline LY & 100 & 33 & 2 & & & & & & \\
\hline 135 & 0.741 & 0.244 & 0.015 & 0.863 & 0.137 & 0.209 & 0.236 & 1.310 & $0.152(0.697)$ \\
\hline BB & 35 & 4 & 1 & & & & & & \\
\hline 40 & 0.875 & 0.100 & 0.025 & 0.925 & 0.075 & 0.129 & 0.139 & 1.161 & $3.120(0.077)$ \\
\hline
\end{tabular}

B.

\begin{tabular}{|c|c|c|c|c|c|c|c|c|c|}
\hline \multirow[t]{2}{*}{ Breed } & \multicolumn{3}{|c|}{ Observed genotype } & \multicolumn{2}{|c|}{ Allelic frequency } & \multirow[t]{2}{*}{$P I C$} & \multirow[t]{2}{*}{$H_{e}$} & \multirow[t]{2}{*}{$N_{e}$} & \multirow[t]{2}{*}{$\chi^{2}$ test $(\mathrm{P})$} \\
\hline & TT & $\mathrm{TC}$ & $\mathrm{CC}$ & $\mathrm{T}$ & $\mathrm{C}$ & & & & \\
\hline $\mathrm{CH}$ & 239 & 265 & 72 & & & & & & \\
\hline 576 & 0.415 & 0.460 & 0.125 & 0.645 & 0.355 & 0.353 & 0.458 & 1.845 & $0.012(0.912)$ \\
\hline LY & 72 & 54 & 9 & & & & & & \\
\hline 135 & 0.533 & 0.400 & 0.067 & 0.733 & 0.267 & 0.315 & 0.391 & 1.642 & $0.069(0.792)$ \\
\hline BB & 15 & 22 & 3 & & & & & & \\
\hline 40 & 0.375 & 0.550 & 0.075 & 0.650 & 0.350 & 0.351 & 0.455 & 1.835 & $1.743(0.187)$ \\
\hline
\end{tabular}

C.

\begin{tabular}{|c|c|c|c|c|c|c|c|c|c|}
\hline \multirow[t]{2}{*}{ Breed } & \multicolumn{3}{|c|}{ Observed genotype } & \multicolumn{2}{|c|}{ Allelic frequency } & \multirow[t]{2}{*}{$P I C$} & \multirow[t]{2}{*}{$H_{e}$} & \multirow[t]{2}{*}{$N_{e}$} & \multirow[t]{2}{*}{$\chi^{2}$ test $(\mathrm{P})$} \\
\hline & AA & $\mathrm{AG}$ & GG & A & G & & & & \\
\hline$\overline{\mathrm{CH}}$ & 255 & 269 & 52 & & & & & & \\
\hline 576 & 0.443 & 0.467 & 0.090 & 0.676 & 0.324 & 0.342 & 0.438 & 1.779 & $2.547(0.111)$ \\
\hline LY & 77 & 45 & 13 & & & & & & \\
\hline 135 & 0.570 & 0.333 & 0.096 & 0.737 & 0.263 & 0.313 & 0.388 & 1.633 & $2.648(0.104)$ \\
\hline BB & 14 & 20 & 6 & & & & & & \\
\hline 40 & 0.350 & 0.500 & 0.150 & 0.600 & 0.400 & 0.365 & 0.480 & 1.923 & $0.069(0.792)$ \\
\hline
\end{tabular}

$\mathrm{CH}=$ Chinese Holstein breed; LY $=$ Luxi Yellow breed; BB = Bohai Black breed; $H_{e}=$ heterozygosities; $N_{e}=$ effective of alleles; $P I C=$ polymorphism information content. 


\section{Association of $T f$ gene polymorphism with milk and health traits in Chinese Holsteins}

SNPs may be useful markers for identifying genes that contribute to susceptibility to common diseases (Kruglyak, 1999), and SNP analysis may be an efficient tool for characterizing genes that predispose to iron overload or deficiency. We analyzed the associations of these three SNPs with milk production traits including fat content, protein content, 305-day milk yield, and SCS in Chinese Holsteins (Table 3). At locus g.13942T $>C$, cows with genotype $C C$ had higher SCS than the ones with genotypes TC $(\mathrm{P}<0.05)$ and $T T(\mathrm{P}<0.01)$, and the additive effect of SCS was significant $(\mathrm{P}<0.05)$. This suggests a possible role of this SNP in the host response against mastitis, which is in agreement with the report that there is a significant association between transferrin genotype and somatic cell count in ewe milk (Steppa et al., 2009). Also, some transferrins are associated with resistance and susceptibility to disease (Enns and Sussman, 1981; Brandon et al., 1999). The possible explanations for this are 4-fold. First, the SNP g.13942T $>$ C in exon 8 is a synonymous mutation [TTA (Leu) $>$ CTA (Leu)] at the 326th amino acid near the $\mathrm{C}$-terminal $\mathrm{Fe}^{3+}$ binding sites. Second, bacterial pathogens are the most common causes of mastitis in cows. As a major glycoprotein in iron metabolism in many species including cattle, transferrin ensures the transfer of $\mathrm{Fe}^{3+}$ ions from sites of absorption and heme degradation, through biological fluids, to sites of storage and utilization (Lambert et al., 2005). The antibacterial function of $\mathrm{Tf}$ is related to the sequestration of free iron necessary for bacterial growth. Third, the antimicrobial action of $\mathrm{Tf}$ is likely independent of iron, and is related to the ability of apo-Tf to reduce the adhesion of Gram-positive and Gram-negative bacteria to surfaces (Ardehali et al., 2003). Lastly, some transferrin variants are linked to diseases. For example, Beckman and Beckman (1986) propose that in humans, Tf C2 is associated with diseases of free radical etiology; while Wedekind (1994) suggests that selection after mating may favor heterozygosity or even certain allele combinations at loci that are involved in parasite-host co-evolution.

\begin{tabular}{|c|c|c|c|c|c|}
\hline Locus & Genotype & Fat percentage & Protein percentage & 305-day milk yield $(\mathrm{kg})$ & SCS \\
\hline \multirow{3}{*}{ g. $-1748 \mathrm{G}>A$} & GG & $3.40 \pm 0.08$ & $3.03 \pm 0.06$ & $6638.6 \pm 243.2^{\mathrm{ab}}$ & $4.31 \pm 0.27$ \\
\hline & GA & $3.34 \pm 0.08$ & $3.03 \pm 0.07$ & $6922.6 \pm 250.8^{\mathrm{a}}$ & $4.19 \pm 0.28$ \\
\hline & AA & $3.26 \pm 0.19$ & $2.84 \pm 0.16$ & $6179.4 \pm 528.3^{b}$ & $5.04 \pm 0.53$ \\
\hline Additive effect & & $-0.07 \pm 0.09$ & $-0.09 \pm 0.07$ & $-229.6 \pm 239.7$ & $0.37 \pm 0.24$ \\
\hline Dominance effect & & $0.002 \pm 0.10$ & $0.10 \pm 0.08$ & $517.6 \pm 268.5^{*}$ & $-0.48 \pm 0.27$ \\
\hline \multirow{3}{*}{ g.13942T $>C$} & TT & $3.30 \pm 0.09$ & $3.02 \pm 0.06$ & $6820.9 \pm 243.7$ & $4.10 \pm 0.21^{\mathrm{Bb}}$ \\
\hline & TC & $3.29 \pm 0.09$ & $3.03 \pm 0.06$ & $6676.8 \pm 248.4$ & $4.15 \pm 0.21^{\mathrm{b}}$ \\
\hline & $\mathrm{CC}$ & $3.28 \pm 0.10$ & $3.06 \pm 0.08$ & $6555.1 \pm 292.3$ & $4.51 \pm 0.24^{\mathrm{Aa}}$ \\
\hline Additive effect & & $-0.006 \pm 0.03$ & $0.02 \pm 0.03$ & $-132.9 \pm 96.7$ & $0.20 \pm 0.08^{*}$ \\
\hline Dominance effect & & $0.004 \pm 0.04$ & $-0.01 \pm 0.04$ & $-11.2 \pm 132.1$ & $-0.15 \pm 0.11$ \\
\hline \multirow[t]{3}{*}{ g. $14037 \mathrm{~A}>\mathrm{G}$} & $\mathrm{AA}$ & $3.39 \pm 0.08$ & $3.02 \pm 0.06^{\mathrm{ab}}$ & $6888.6 \pm 247.6^{\mathrm{a}}$ & $4.19 \pm 0.27$ \\
\hline & AG & $3.40 \pm 0.08$ & $3.07 \pm 0.06^{\mathrm{a}}$ & $6616.9 \pm 243.8^{b}$ & $4.34 \pm 0.27$ \\
\hline & GG & $3.26 \pm 0.11$ & $2.89 \pm 0.09^{b}$ & $6854.4 \pm 303.9^{\mathrm{ab}}$ & $4.17 \pm 0.34$ \\
\hline Additive effect & & $0.06 \pm 0.05$ & $0.07 \pm 0.04$ & $17.1 \pm 110.2$ & $0.009 \pm 0.12$ \\
\hline Dominance effect & & $0.08 \pm 0.06$ & $0.12 \pm 0.05^{*}$ & $-254.7 \pm 141.6$ & $0.18 \pm 0.16$ \\
\hline
\end{tabular}

Values with small ( $\mathrm{a}$ and $\mathrm{b}$ ) and capital (A and B) superscript letters within the same row in the same locus denote significant difference at $\mathrm{P}<0.05$ and $\mathrm{P}<0.01$, respectively. Asterisks indicate differences of the locus with additive effect or dominance effect at $\mathrm{P}<0.05$. SCS $=$ somatic cell score. 
Our results showed that cows with genotype $G A$ at locus g.-1748G $>$ A had higher 305 -day milk yield $(\mathrm{P}<0.05)$ than the ones with genotype $A A$, and the dominance effect of 305-day milk yield was significant $(\mathrm{P}<0.05)$. When using TESS (http://www.cbil.upenn. edu/cgi-bin/tess/tess) to predict the $5^{\prime}$ flanking sequence of $T f$ gene, we found that the SNP g.-1748G $>$ A allele $\mathrm{G}$ was located in a putative selective $\mathrm{T}$ lymphocyte-specific transcription factor binding site. When $\mathrm{G}$ was converted to $\mathrm{A}$, the binding sites were eliminated. DouabinGicquel et al. (2001) reported that g. $-733 \mathrm{~A}>\mathrm{G}$ and g. $+47 \mathrm{G}>\mathrm{A}$ SNPs were located in the 5'-UTR of the human transferrin gene. 5'-UTRs are known to play crucial roles in post-transcriptional regulation, including modulations of the transport of mRNAs out of the nucleus, translation efficiency, and subcellular localization (Jansen, 2001) and stability (Bashirullah et al., 2001). Under this assumption, changes in gene transcription caused by mutations at g.-1748G $>$ A in the essential region (5'-UTR) of the $T f$ gene could result in the variations of milk traits of cattle.

Cows with genotype $A G$ at locus g.14037A $>\mathrm{G}$ had higher protein content than the ones with genotype $G G(\mathrm{P}<0.05)$, cows with genotype $A A$ had higher 305 -day milk yield than the ones with genotype $A G(\mathrm{P}<0.05)$, and the dominance effect of the protein content was significant $(\mathrm{P}<0.05)$. Majewski and Ott (2002) reported that the regions within $20 \mathrm{bp}$ from the intron recognition sites GT and AG had major impacts on intron splicing. Since the SNP g.14037A $>$ G is 9 bp downstream of the $5^{\prime}$ intron splicing site (GT), it may directly affect the splicing of intron 8. In addition, although introns do not encode proteins, they are important in regulating gene expression and splicing (Nott et al., 2003). Whether the detected mutations in intron 8 regulate bovine $T f$ gene expression or not needs to be clarified.

The above results suggest that cattle with genotypes $G A, T T$ and $A A$ had higher 305day milk yield, higher protein content and lower SCS. Accordingly, genetic variations of $T f$ gene in dairy cattle are significant for breeding.

Bovine transferrin is encoded by the Tf gene, which is located at $125 \mathrm{cM}$ on bovine chromosome 1 (Kappes et al., 1997). Suggestive quantitative trait loci have been detected for fat yield at $50 \mathrm{cM}$ (Casas et al., 2004). Sanz et al. (2010) reported that SNP c. $1455 \mathrm{~A}>\mathrm{G}$ in exon 12 of $T f$ had a significant association $(\mathrm{P}<0.0006)$ with high fat production in Holstein-Friesian animals. However, in the present study, no significant associations of these SNPs with fat content were detected at the three loci in the populations analyzed $(\mathrm{P}>0.05)$.

Three SNPs (g.-1748G $>$ A, g.13942T $>$ C and g.14037A $>$ G) were used for haplotype reconstruction. The haplotypes were H1 (GTA), H2 (GCG), H3 (ATA), H4 (GCA), H5 (GTG), H6 (ATG), H7 (ACA), and H8 (ACG), and the estimated haplotype frequencies were $45.4,25.0,11.9,9.8,5.7,1.5,0.5$, and $0.2 \%$, respectively. H1 had the highest haplotype frequencies and $\mathrm{H} 8$ had the lowest haplotype frequencies. Combinations of two of the haplotypes were used to analyze the correlation among haplotype combinations, milk production traits and health traits (Table 4). Nineteen haplotype combinations of $T f$ were detected in the cows tested. The number of individuals with haplotype combinations $\mathrm{H} 2 \mathrm{H} 8$ (GACCGG), H5H6 (GATTGG), H6H6 (AATTGG), H3H6 (AATTAG), H5H5 (GGTTGG), and $\mathrm{H} 4 \mathrm{H} 7$ (GACCAA) was less than 5, without statistical significance. Accordingly, the associations were not analyzed among these haplotype combinations, milk traits and health traits of Chinese Holsteins. 
Table 4. Effect of different combinations of three SNPs (g.-1748G $>$ A, g.13942T $>$ C and g. 14037A $>$ G) on milk production traits in Chinese Holstein $(\mathrm{N}=576)$.

\begin{tabular}{lccccc}
\hline Haplotype combination & Number of combinations & Fat content $(\%)$ & Protein content $(\%)$ & 305-day milk yield (kg) & SCS \\
\hline H1H2 (GGTCAG) & 159 & $3.47 \pm 0.09$ & $3.08 \pm 0.07$ & $6697.0 \pm 269.7^{\mathrm{ab}}$ & $4.64 \pm 0.29$ \\
H1H1 (GGTTAA) & 113 & $3.48 \pm 0.09$ & $3.05 \pm 0.08$ & $6866.1 \pm 278.9$ & $4.41 \pm 0.31$ \\
H1H3 (GATTAA) & 67 & $3.39 \pm 0.11$ & $3.06 \pm 0.09$ & $7159.1 \pm 299.9^{\mathrm{acd}}$ & $4.46 \pm 0.33$ \\
H1H8 (GATCAG) & 41 & $3.38 \pm 0.12$ & $3.11 \pm 0.10$ & $6636.7 \pm 329.9^{\mathrm{e}}$ & $4.49 \pm 0.37$ \\
H1H4 (GGTCAA) & 40 & $3.39 \pm 0.13$ & $3.06 \pm 0.11$ & $6652.8 \pm 346.7^{\mathrm{f}}$ & $4.45 \pm 0.38$ \\
H2H2 (GGCCGG) & 30 & $3.29 \pm 0.14$ & $3.00 \pm 0.11$ & $6602.8 \pm 361.7^{\mathrm{cgH}}$ & $4.41 \pm 0.40^{\mathrm{a}}$ \\
H1H5 (GGTTAG) & 27 & $3.33 \pm 0.15$ & $3.15 \pm 0.12$ & $6368.2 \pm 368.2^{\mathrm{i}}$ & $4.01 \pm 0.42$ \\
H2H4 (GGCCAG) & 23 & $3.58 \pm 0.15$ & $3.19 \pm 0.12^{\mathrm{a}}$ & $6416.4 \pm 387.4^{\mathrm{dj}}$ & $4.95 \pm 0.43^{\mathrm{ab}}$ \\
H1H6 (GATTAG) & 17 & $3.47 \pm 0.17$ & $3.16 \pm 0.14$ & $7251.6 \pm 391.8^{\mathrm{g}}$ & $4.33 \pm 0.44$ \\
H2H5 (GGTCGG) & 15 & $3.31 \pm 0.18$ & $2.85 \pm 0.15^{\mathrm{ab}}$ & $7584.8 \pm 450.1^{\mathrm{befj} H}$ & $4.56 \pm 0.51$ \\
H4H4 (GGCCAA) & 14 & $3.60 \pm 0.18$ & $3.24 \pm 0.15^{\mathrm{b}}$ & $6849.2 \pm 453.8$ & $4.52 \pm 0.52$ \\
H3H4 (GATCAA) & 10 & $3.17 \pm 0.19$ & $2.95 \pm 0.16$ & $6907.2 \pm 494.4$ & $3.64 \pm 0.57^{\mathrm{b}}$ \\
H3H3 (AATTAA) & 7 & $3.48 \pm 0.24$ & $2.92 \pm 0.19$ & $6493.5 \pm 676.4$ & $4.83 \pm 0.64$ \\
\hline
\end{tabular}

Means with the same small letters within the same row differ at $\mathrm{P}<0.05$. Means with the same capital letters within the same row differ at $\mathrm{P}<0.01$. Means marked with different superscript or without any superscript do not differ statistically. H1 = GTA; H2 = GCG; H3 = ATA; H4 = GCA; H5 = GTG; H6 = ATG; H7 = ACA; H8 = ACG.

The association analysis results showed that individuals with haplotype combination $\mathrm{H} 4 \mathrm{H} 4$ had the highest protein and fat contents, which suggested that this haplotype combination $(\mathrm{N}=14)$ was a dominant combination of alleles for protein and fat contents. Individuals with haplotype combination $\mathrm{H} 2 \mathrm{H} 5$ had the highest 305-day milk yield, and it was higher than in the ones with haplotype combinations $\mathrm{H} 1 \mathrm{H} 2, \mathrm{H} 1 \mathrm{H} 8, \mathrm{H} 1 \mathrm{H} 4, \mathrm{H} 1 \mathrm{H} 5, \mathrm{H} 2 \mathrm{H} 2$, and $\mathrm{H} 2 \mathrm{H} 4$ (P $<0.05$ ). As a result, high 305-day milk yield can be obtained by breeding cows with haplotype combination $\mathrm{H} 2 \mathrm{H} 5$. Individuals with haplotype combination $\mathrm{H} 3 \mathrm{H} 4$ had the lowest $\mathrm{SCS}$. Accordingly, $\mathrm{H} 4 \mathrm{H} 4, \mathrm{H} 2 \mathrm{H} 5$ and $\mathrm{H} 3 \mathrm{H} 4$ should be used as molecular markers in the future for the selection of cattle with high protein content, high 305-day milk yield, and low SCS, respectively. Fallin et al. (2001) considered that the inheritance of haplotype combinations was more effective than that of a single SNP. The genotype effect of one SNP may be influenced by other SNPs; while a haplotype combination provides a comprehensive way of assessing the relationship between multiple-site variation and traits. Consequently, the analysis of haplotype combination is superior to the analysis of a single SNP. Furthermore, these results may be instructional for early breeding selection of the Chinese Holstein breed.

Although the effect of the detected genetic variation on $T f$ gene expression remains to be explored, the SNPs of the $T f$ gene possibly contribute to association analysis, and $T f$ can be used as a genetic marker in milk production and mastitis-related traits for animal breeding and genetics.

\section{Expression of the bovine $T f$ mRNA}

We also investigated the differences in $T f$ gene expression between normal and mastitis mammary tissues in 10 cows (Figure 3). Our quantitative data indicated that the $T f$ mRNA level was higher in mastitis mammary tissue than in normal mammary tissues, and that no significant difference was found between the two types of mammary tissues. Interestingly, Kmiec (1998) reported that the transferrin content in milk was higher in animals with diagnosed mastitis than that in healthy animals. Also, the lactotransferrin gene expression 
in $S$. uberis-infected mammary tissues was higher than that in healthy mammary tissues [3.4-fold (22 EST) in a microarray experiment and 6.5-fold in qRT-PCR analysis] (Swanson et al., 2009). The possible explanation is that $\mathrm{Tf}$ inhibits bacterial growth by chelating iron, an important nutrient element for many bacteria and viruses. When mammary tissue is invaded by bacteria and develops mastitis, the $T f$ gene expression in the mammary tissue is increased, so g.13942T $>$ C of Tf may play an important role in genetic susceptibility to bovine mastitis.

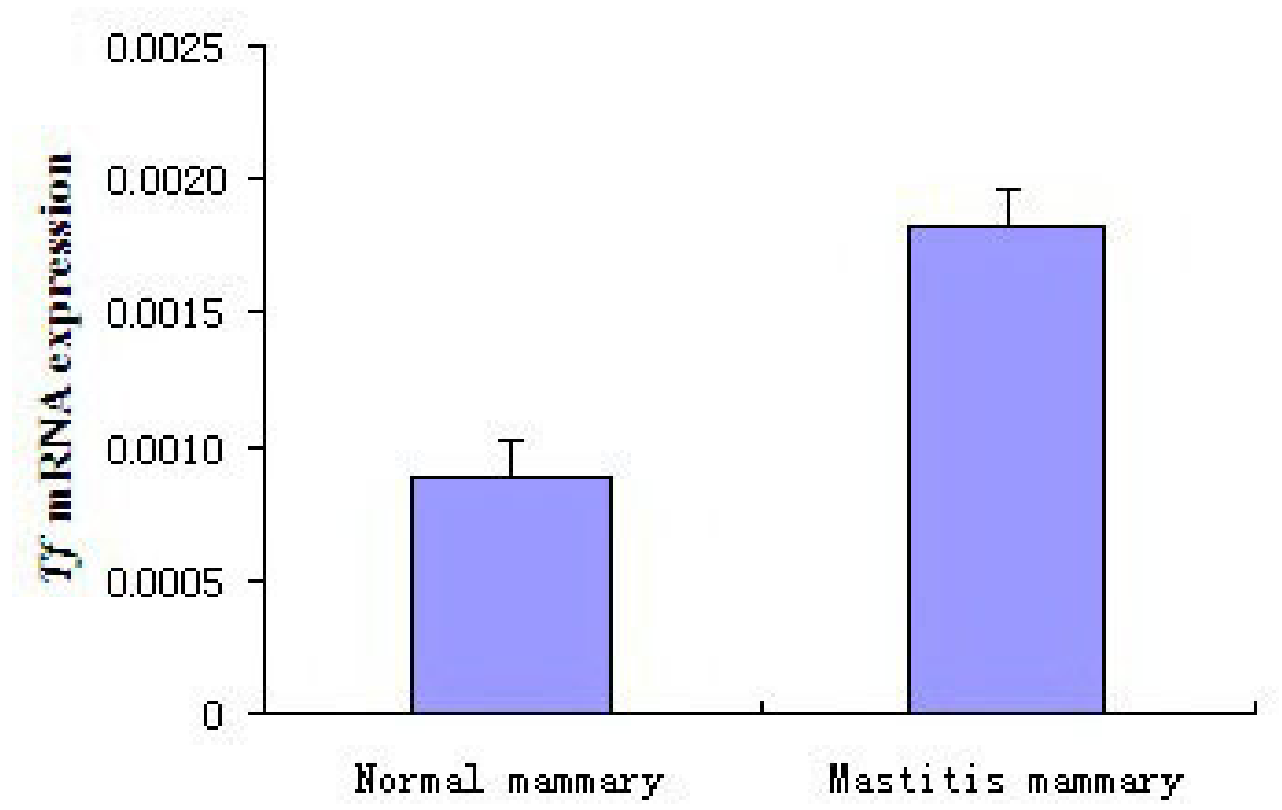

Figure 3. Quantitative polymerase chain reaction analysis of $T f$ mRNA expression in normal and mastitis tissues.

In summary, three novel SNPs and the association between $T f$ gene and milk production and health traits in dairy cattle are reported. In addition, the $T f$ gene expression levels were investigated in normal and mastitis mammary tissues. Cows with haplotype combinations $\mathrm{H} 3 \mathrm{H} 4, \mathrm{H} 4 \mathrm{H} 4$ and $\mathrm{H} 2 \mathrm{H} 5$ should be used as the molecular markers for the selection of cattle with low SCS, high protein content, and high 305-day milk yield, respectively. These results suggest that $T f$ gene is a candidate gene that influences milk production traits and that can be implemented in breeding programs to obtain healthy Chinese Holstein with excellent milk quality.

\section{ACKNOWLEDGMENTS}

Research supported by the National "863" Program of China (\#2007AA10Z169 and \#2006AA10Z1D9), National Cow Industrial Technology System Program (\#nycytx-0107 and \#nyhyzx07-036-09), Well-bred Program from Shandong province (\#2007LZ10-06), and Key Scientific and Technological Project from Shandong province (\#2009GG20002033). 


\section{REFERENCES}

Ardehali R, Shi L, Janatova J, Mohammad SF, et al. (2003). The inhibitory activity of serum to prevent bacterial adhesion is mainly due to apo-transferrin. J. Biomed. Mater. Res. A 66: 21-28.

Ashton GC, Fallon GR and Suthcrland DN (1964). Transferrin ( $\beta$-globulin) type and milk and butterfat production in dairy cows. J. Agric. Sci. 62: 27-34.

Bashirullah A, Cooperstock RL and Lipshitz HD (2001). Spatial and temporal control of RNA stability. Proc. Natl. Acad. Sci. U. S. A. 98: 7025-7028.

Beckman L and Beckman G (1986). Transferrin C2 as an enhancer of cyto- and genotoxic damage. Prog. Clin. Biol. Res. 209B: 221-224.

Bond R, Kim JY and Lloyd DH (2005). Bovine and canine transferrin inhibit the growth of Malassezia pachydermatis in vitro. Med. Mycol. 43: 447-451.

Brandon RB, Giffard JM and Bell K (1999). Single nucleotide polymorphisms in the equine transferrin gene. Anim. Genet. 30: 439-443.

Casas E, Keele JW, Shackelford SD, Koohmaraie M, et al. (2004). Identification of quantitative trait loci for growth and carcass composition in cattle. Anim. Genet. 35: 2-6.

Chaneton L, Tirante L, Maito J, Chaves J, et al. (2008). Relationship between milk lactoferrin and etiological agent in the mastitic bovine mammary gland. J. Dairy Sci. 91: 1865-1873.

Chowdhary BP, Raudsepp T, Fronicke L and Scherthan H (1998). Emerging patterns of comparative genome organization in some mammalian species as revealed by Zoo-FISH. Genome Res. 8: 577-589.

Douabin-Gicquel V, Soriano N, Ferran H, Wojcik F, et al. (2001). Identification of 96 single nucleotide polymorphisms in eight genes involved in iron metabolism: efficiency of bioinformatic extraction compared with a systematic sequencing approach. Hum. Genet. 109: 393-401.

Enns CA and Sussman HH (1981). Physical characterization of the transferrin receptor in human placentae. J. Biol. Chem. 256: 9820-9823.

Fallin D, Cohen A, Essioux L, Chumakov I, et al. (2001). Genetic analysis of case/control data using estimated haplotype frequencies: application to APOE locus variation and Alzheimer's disease. Genome Res. 11: 143-151.

Fletcher J and Huehns ER (1968). Function of transferrin. Nature 218: 1211-1214.

Gahne B, Juneja RK and Grolmus J (1977). Horizontal polyacrylamide gradient gel electrophoresis for the simultaneous phenotyping of transferrin, post-transferrin, albumin and post-albumin in the blood plasma of cattle. Anim. Blood Groups Biochem. Genet. 8: 127-137.

Heringstad B, Klemetsdal G and Ruane J (2000). Selection for mastitis resistance in dairy cattle: a review with focus on the situation in the Nordic countries. Livest. Prod. Sci. 64: 95-106.

Huang J, Wang H, Wang C, Li J, et al. (2010). Single nucleotide polymorphisms, haplotypes and combined genotypes of lactoferrin gene and their associations with mastitis in Chinese Holstein cattle. Mol. Biol. Rep. 37: 477-483.

Jansen RP (2001). mRNA localization: message on the move. Nat. Rev. Mol. Cell. Biol. 2: 247-256.

Kappes SM, Keele JW, Stone RT, McGraw RA, et al. (1997). A second-generation linkage map of the bovine genome. Genome Res. 7: 235-249.

Khatib H, Zaitoun I, Chang YM, Maltecca C, et al. (2007). Evaluation of association between polymorphism within the thyroglobulin gene and milk production traits in dairy cattle. J. Anim. Breed. Genet. 124: 26-28.

Kmiec M (1998). Transferyna- bia ko pe niace wiele ról w organizmie. Przegl. Hodowlany 1: 8-9.

Kruglyak L (1999). Prospects for whole-genome linkage disequilibrium mapping of common disease genes. Nat. Genet. 22: $139-144$.

Lambert LA, Perri H, Halbrooks PJ and Mason AB (2005). Evolution of the transferrin family: conservation of residues associated with iron and anion binding. Comp. Biochem. Physiol. B. Biochem. Mol. Biol. 142: 129-141.

Larionov A, Krause A and Miller W (2005). A standard curve based method for relative real time PCR data processing. BMC Bioinformatics 6: 62.

Liu W, Wang J, Li Q, Ju Z, et al. (2010). Correlation analysis between three novel SNPs of the Src gene in bovine and milk production traits. Mol. Biol. Rep. 37: 3771-3777.

MacGillivray RT, Mendez E, Sinha SK, Sutton MR, et al. (1982). The complete amino acid sequence of human serum transferrin. Proc. Natl. Acad. Sci. U. S. A. 79: 2504-2508.

Majewski J and Ott J (2002). Distribution and characterization of regulatory elements in the human genome. Genome Res. 12: $1827-1836$

Mason C (2006). Basic mastitis bacteriology: untangling the pathogens. Ir. Vet. J. 59: 453-459.

Nott A, Meislin SH and Moore MJ (2003). A quantitative analysis of intron effects on mammalian gene expression. RNA 
9: 607-617.

Poso J and Mantysaari EA (1996). Relationships between clinical mastitis, somatic cell score, and production for the first three lactations of Finnish Ayrshire. J. Dairy Sci. 79: 1284-1291.

Retzer MD, Kabani A, Button LL, Yu RH, et al. (1996). Production and characterization of chimeric transferrins for the determination of the binding domains for bacterial transferrin receptors. J. Biol. Chem. 271: 1166-1173.

Rupp R and Boichard D (1999). Genetic parameters for clinical mastitis, somatic cell score, production, udder type traits, and milking ease in first lactation Holsteins. J. Dairy Sci. 82: 2198-2204.

Sanz A, Ordovas L, Serrano C, Zaragoza P, et al. (2010). A single nucleotide polymorphism in the coding region of bovine transferrin is associated with milk fat yield. Genet. Mol. Res. 9: 843-848.

Seegers H, Fourichon C and Beaudeau F (2003). Production effects related to mastitis and mastitis economics in dairy cattle herds. Vet. Res. 34: 475-491.

Sevi A, Taibi L, Albenzio M, Annicchiarico G, et al. (2001). Airspace effects on the yield and quality of ewe milk. $J$. Dairy Sci. 84: 2632-2640.

Shi YY and He L (2005). SHEsis, a powerful software platform for analyses of linkage disequilibrium, haplotype construction, and genetic association at polymorphism loci. Cell Res. 15: 97-98.

Steppa R, Wójtowskl J, Bielinska S and Keszycka M (2009). Effect of transferrin and haemoglobin polymorphism on hygienic quality of milk in sheep. Züchtungskunde 81: 125-132.

Swanson KM, Stelwagen K, Dobson J, Henderson HV, et al. (2009). Transcriptome profiling of Streptococcus uberisinduced mastitis reveals fundamental differences between immune gene expression in the mammary gland and in a primary cell culture model. J. Dairy Sci. 92: 117-129.

Tao Q, Yu MX, Zhao YH and Wang DX (2007). Survey of incidence of cow mastitis in west Liaoning and the integrated control measures. China Cattle Sci. 4: 61-63 (in Chinese).

Wedekind C (1994). Mate choice and maternal selection for specific parasite resistances before; during and after fertilization. Philos. Trans. R. Soc. Lond. B. Biol. Sci. 346: 303-311.

Zhang F, Huang J, Li Q, Ju Z, et al. (2010). Novel single nucleotide polymorphisms (SNPs) of the bovine STAT4 gene and their associations with production traits in Chinese Holstein cattle. Afr. J. Biotechnol. 9: 4003-4008.

Zhang YH, Pan YS, Gao Y, Ma Q, et al. (2008). Studies on transferrin and posttremsferr polymorphism and their relationship with performances in red steppe. Agric. Sci. Technol. 9: 109-112. 